\title{
Regional Differentiation of Labour Productivity and Distribution of Value Added
}

\author{
Elena N. Pochekutova* \\ Siberian Federal University \\ 79 Svobodny, Krasnoyarsk, 660041, Russia
}

Received 20.11.2018, received in revised form 29.10.2019, accepted 04.12.2019

The article deals with the issue of the distribution of value added in the course of wage formation. Improvement of the efficiency of social production in Russia is associated with the need for innovative, technological changes that should lead to an increase in labor productivity. The Russian Federation is not a country with a high level of production efficiency. Frequently, this very fact is the reason for justifying the low wages in the country. The paradox of the existence of the category of working citizens - "the working poor" - in the country is based, among other things, on a low level of guaranteed incomes - the minimum wage. The minimum wage until May 1, 2018 did not meet the minimum wage. Neither in economic theory nor in the practice of national economies does there exist an "optimal" correlation of the distribution of value added between employees and owners. Yet, the ratio of the minimum wage to the value added rather vividly characterizes the fairness of the current systems of relations in the labour market, this phenomenon being termed "the freedom of work" by a number of experts. The size of the average wage in the region depends on the presence of high value added industries in the territory, i.e. on industry specialization. The established practice in Russia is as follows: the higher the level of average wage is, the lower the share of value added per wage is. Regions without specialization in high value-added economic activities will more realistically assess the level of socio-economic development, basing their strategic development on industries that form more equitable wage systems and equalize the average wage.

Keywords: labour productivity, social production efficiency, value added per employee, share of wages, subject of the Russian Federation.

Research area: economics.

Citation: Pochekutova, E.N. (2019). Regional differentiation of labour productivity and distribution of value added. J. Sib. Fed. Univ. Humanit. Soc. Sci., 12(12), 2290-2308. DOI: $10.17516 / 1997-1370-0523$.

(C) Siberian Federal University. All rights reserved

* Corresponding author E-mail address: potschekutova@mail.ru ORCID: 0000-0002-4252-4203

This work is licensed under a Creative Commons Attribution-NonCommercial 4.0 International License (CC BY-NC 4.0). 


\section{Introduction}

The decree of the President of the Russian Federation "On the national goals and strategic objectives of the development of the Russian Federation for the period up to 2024" defined the strategic goals of the development of the Russian Federation (Ukaz Prezidenta 204). Socio-economic development of the country should be based on scientific and technological development of the national economy, which will provide improved living standards, comfortable conditions for the citizens' residence, and conditions and opportunities for each personality's self-realization and talent. One of the strategic directions of the country's development will be the labour productivity growth and the guarantee for high employment.

In Russia, there have been rather long discussions about the low level of labour productivity, the need to ensure a proportional wage growth in line with the growth of efficient use of labour resources. The severity of the debate is due to the following dilemma: wage growth, its share in value-added products leads to lower profits and, consequently, to lower business investment opportunities. Unfortunately, in the case of choice between wage growth and investment the decision is not made in favor of employees. It is also noted that "in general the share of wages in GDP, achieved in Russia, corresponds to the norms accepted in the world and its further growth can hardly be considered expedient". The possibility of wage growth is due to the steady growth of the national economy as a whole, this is what the main efforts should be aimed at (Sobolev, 2017: 13). It can be considered that this principle is adhered to not only by business owners / employers, but also by the state.

The ratio of the minimum wage to the average value added per an employee in the economy reflects the measure of distribution of value added guaranteed by the state. However, the lower the minimum wage is, the more opportunities businesses have to understate the cost of labour and, that is even more dangerous for the national economy, to transfer part of wages to the shadow sector.

\section{Theoretical framework}

Formation of strategic directions, ensuring the economic growth in modern Russia, should be correlated with one significant limitation of the development, the limitation being the number of working-age population. Some researchers note that "in the future, in the next 15-20 years, they are impossible not only due to the lack of competitiveness of domestic products, but also due to labour intensity caused by current restrictions on labour resources" (Uziakov, Shirokov, 2012: 17). The authors 
further note that "convergence of the indicators of the labour productivity level with the levels achieved by developed countries should be regarded in the aspect of not only labour efficiency, but also of labour costs equalization" (Uziakov, Shirokov, 2012: 18).

Leading Russian economists claim that Russia has not yet achieved the productivity growth. "This requires a new technological base of production with more advanced technology, on the one hand, and highly skilled and professional workforce with both knowledge and skills and abilities, on the other hand" (Aganbegian, 2017: 19). The increase in labour productivity must necessarily be accompanied by the increase in wages, which, among other things, will smooth out high differentiation of the citizens' incomes (Aganbegian, 2017: 19).

\section{Problem Statement}

The subjects of the Russian Federation with the enterprises with high added value always show good results in interregional comparisons of economic development. Oriented towards traditional indicators when making interregional or all-Russian comparisons, the leading regions eventually become hostages of illusions of stability of the territory's economic well-being. This results in preservation of current industrial structure of the region's economy. When assessing the social production efficiency in terms of labour resources involvement in the region's economy, it is necessary to assess the productivity not only in the region as a whole, but regard its industry specialization. Russian practice is the following: the higher the labour productivity in the industry is, the lower the share of value added is, value added being distributed to the employed in the form of wages. The owners, determining the policy of remuneration, are guided by the average level of wages, thus, obviously making a significant contribution to this very level of wages. So, it is in this situation when the regions fall into a specific trap: high value added - high average wages - low share of wages in value added.

The article assesses the share of average annual wages of the employees in organizations to the value added per an employee in the regions of the Siberian Federal District. The results of the analysis prove that in the regions with high value added industries the industry structure is conserved and the rate of wage growth slows down.

\section{Methods}

The indicator of "the share of average annual wages of employees of organizations to the value added per employee" in the subject of the Russian Federation was calculated according to the formula (1). 


$$
S h_{A A W / V A}=\frac{\text { average annual accrued wages of employees of organizations }}{\text { value added per employee }} * 100 \%
$$

$S h_{A A W}$ - the share of average annual accrued wages of employees of organizations in value added per employee in the subject of the Russian Federation; average annual accrued wages of employees of organizations - average annual accrued wages per employee of organizations in the subject of the Russian Federation.

The indicator of the average annual accrued wages is calculated by multiplying the "average monthly accrued wages of employees of organizations in the subjects of the Russian Federation" indicator by 12.

The "value added per employee in the subject of the Russian Federation|" indicator is calculated as per the formula (2).

$$
A V=\frac{G R P}{N E}
$$

$A V$ - added value per employee in the subject of the Russian Federation; GRP physical volume of gross regional product in basic prices; $N E$ - the number of employees aged 15-72 years in the subject of the Russian Federation.

The "value added per employee in the subject of the Russian Federation" indicator is essentially the indicator of assessing the efficiency of labour resources use, i.e. the indicator of labour productivity in the subject of the Russian Federation. However, according to the official methodology approved by the Ministry of Economic Development of the Russian Federation, labour productivity in the subject of the Russian Federation is calculated as per the formula (3) (Prikaz 274)

$$
L P=\frac{G R P}{L C},
$$

$L P$ - labour productivity; GRP — gross regional product in the subjects of the Russian Federation (gross value added in basic prices); $L C$ - total labor costs in the region.

Should we follow the methodology proposed by the Ministry of Economic Development of the Russian Federation? We should, if the purpose of the research is to assess the level of employment and the effectiveness of one working hour per employee. It is this indicator which is calculated by the Federal State Statistics Service of the Russian Federation as that of labour productivity in the economy as a whole and in the main types of economic activity producing market goods and services. 
This method of productivity calculation is acceptable only if the researchers compare productivity growth and hourly wages, adopted in the United States, for example. The ratio of the growth of average wages and labour productivity is still worth pursuing if labour productivity is calculated by the formula (1), i.e. as value added per employee. In the future, this will be an indicator to determine labour productivity, since it allows assessing the efficiency of social production, the efficiency of labour resources use / involvement in the process of production of goods and services.

The value added per employee in the Russian Federation as a whole was calculated as per the data of Rosstat (Federal State Statistics Service). It is regarded as a ratio of the "gross regional product in the subjects of the Russian Federation (gross value added in basic prices)" indicator and the "number of employees aged 15-72 years in the subjects of the Russian Federation" indicator. For calculations, the value of the "gross value added" indicator is used in current prices. The research involves neither the assessment of changes in the physical growth of national production nor the assessment of labour resources contribution to economic growth. Thus, the traditional conversion into fixed prices that would allow assessing the physical output growth was not meant. On the contrary, it is the measurement of gross value added (GVA) at current prices that will allow assessing the proportions of the distribution of value added between business / product owners and employees. Since GVA is calculated in basic prices, the calculation of the indicator does not take into account the taxes on products, the taxes being the resources of the "state institutions" sector in national economic systems. Yet, the subsidies - additional resources for the "non-financial enterprises" sector - are taken into account.

In terms of labour resources involvement in the production process, assessment of the social production efficiency is based on the GRP indicator in basic prices. Industry specialization of the regions determines the differentiation of the subjects of the Russian Federation as per the average monthly accrued wages. The volume and dynamics of GRP of the subject of the Russian Federation is determined by the level of the territory's economic development, including the level of specialization. The specialization coefficients are calculated according to the enlarged section of AllRussian classifier of economic activities (OKVED) according to the formula (4):

$$
K_{i j}=\frac{d_{i j}}{d_{i}},
$$


in which $d i j$ is the share of the $i$-th type of economic activity in the gross regional product of the $j$-th subject of the Russian Federation; $d i$ is the share of the $i$-th type of economic activity in the gross domestic product of the Russian Federation.

The results of the assessment of the value added dynamics per employee in the subjects of the Russian Federation of the Siberian Federal District are presented in Table 1. Calculations of the ratio of the value added share per employee in the subjects of the Russian Federation to the All-Russian value of labour productivity in order to assess the social production effectiveness in the regions are given in Table 2. The dynamics of the "average monthly accrued wages of employees of organizations in the subjects of the Russian Federation" indicator is given as per the data of Rosstat (Federal State Statistics Service) in Table 3. The results of the calculation of the dynamics of the "share of the average annual accrued wages of employees of organizations in value added per employee in the subject of the Russian Federation" indicator are presented in Table 4.

\section{Discussion}

\section{Analysis of the regional differentiation of labour productivity and the distribution of value added}

Generally, in the Russian Federation, gross value added per employee has increased by 846.54 thousand rubles, or $768.81 \%$ for the period under the analysis, the average annual growth rate being $14.47 \%$. In the Siberian Federal District (SFD), the increase has amounted to 694.2 thousand rubles, or $707.36 \%$ in relative terms, the average annual growth rate being $13.94 \%$.

For the 2001-2016 period, the maximum value of the "value added per employee" indicator / labour productivity had been always observed in Krasnoyarsk Krai. Thus, in 2001 the value of labour productivity in Krasnoyarsk Krai exceeded the minimum value in Tyva by 3.2 times, i.e. the social production efficiency was higher by 119.71 thousand rubles per year. In absolute terms, in 2016, the gap between the maximum value of 1270.19 thousand rubles (Krasnoyarsk Krai) and the minimum value of 470.71 thousand rubles (Altai Krai) amounted to 799.48 thousand rubles per year. The average annual growth rates of value added per employee in each subject of the Siberian Federal District were approximately the same: they ranged from a minimum value of $11.68 \%$ in Buryatia to a maximum value of $15.3 \%$ in Altai.

The high value of the "value added per employee" indicator is explained by the location of export-oriented industries with a high share of added value in Krasnoyarsk 


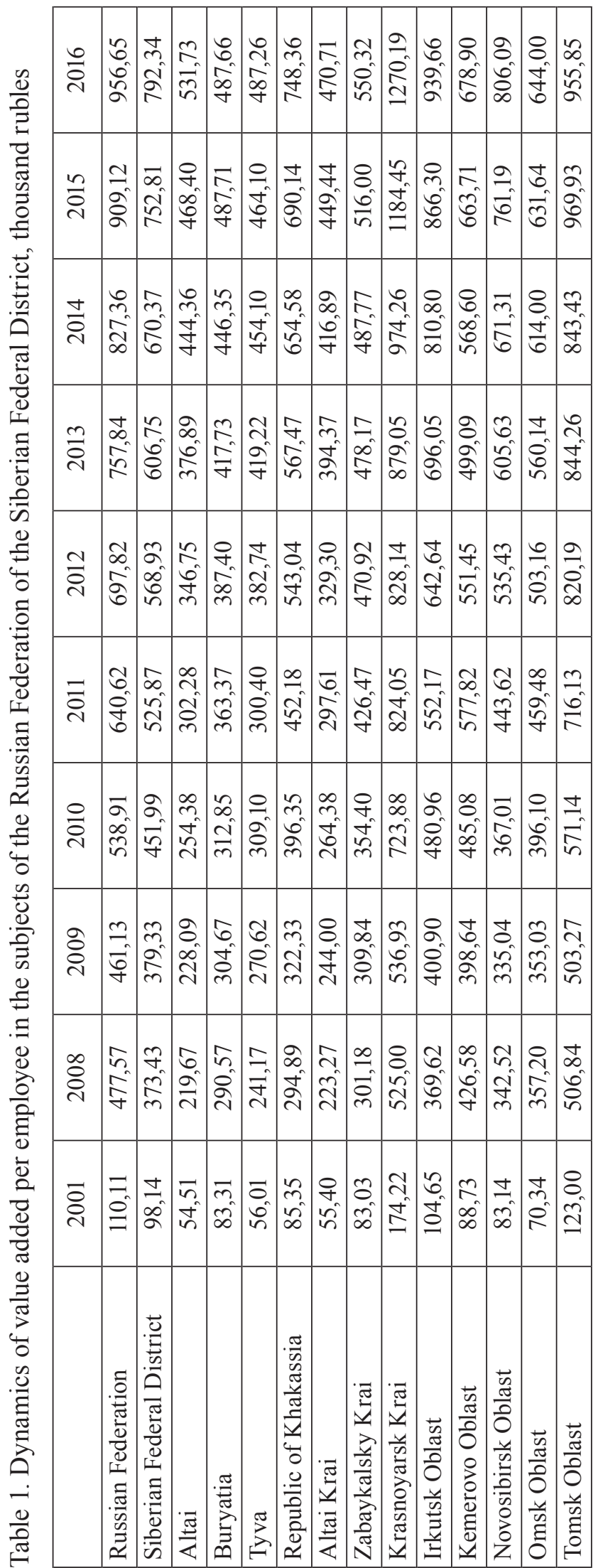


Krai territory, this fact making the region an attractive area for income: the krai has the largest number of employees in the SFD. On the other hand, orientation towards foreign markets leads to the krai's vulnerability to current and possible external risks. The decline in the physical growth volume during the 2008-2009 crisis should be born in mind. In the course of this period, the value growth of specific value added had amounted to only $5.04 \%$ by 2007 . The value of labour productivity in Krasnoyarsk Krai during the entire period of 2001-2016 exceeded the all-Russian value (Table 2).

In Krasnoyarsk Krai, the maximum excess of value added produced by one employee over the national average was observed in 2001 and amounted to $58.2 \%$. The decrease in this value in subsequent years was due to higher growth rates in the Russian Federation. In the course of the 2002-2007 period, the lag in the growth rate of value added per employee in Krasnoyarsk Krai was marked in 2003 and 2005. In 2002 , the value of the indicator decreased by $6.8 \%$, and there was a slight increase in the growth rate of $4.75 \%$ in 2004. A significant increase in labour efficiency of the employed in the economy of Krasnoyarsk Krai was registered in 2010, the growth rate of value added amounted to 134.8 , and the all-Russian increase was exceeded by $17.9 \%$. In 2015, the same excess was $11.7 \%$. In the course of the 2008-2016 period, Krasnoyarsk Krai did not face any decrease in the value added per employee. This made it possible to outpace the national value by $32.8 \%$ by the end of 2016 .

Generally, in the Siberian Federal District, the ratio of value added per employee to the all-Russian value of the indicator varies from the maximum value in 2001 with a share of $89.1 \%$ to the minimum value of $78.2 \%$ in 2008 . In the whole, the trend for the district is negative, as there is no recovery of labour efficiency after the 2008-2009 crisis. Traditionally, the regions with economic gap are Buryatia, Tyva and Altai. For these territories, the ratio of value added produced by one employee to the national value is approximately $50 \%$. In absolute terms, in 2016, the lag of labour efficiency in these subjects of the Russian Federation, regarding the average for the SFD, was 304.68 thousand rubles for Buryatia, 305.08 thousand rubles for Tyva, and 321.63 thousand rubles for Altai.

The slowdown in the development of Zabaykalsky Krai and Kemerovo Oblast should be noted. In Zabaykalsky Krai, an average annual increase in labour efficiency is $12.5 \%$, which led to a decrease in the share of value added per employee compared to the national value. So, in 2001, the share was $78.3 \%$, or 83.03 thousand rubles; in 2016 it was $57.5 \%$, with an absolute value of 550.32 thousand rubles. In 2015, the lag in the efficiency of labour resources use from the average for the district amounted 


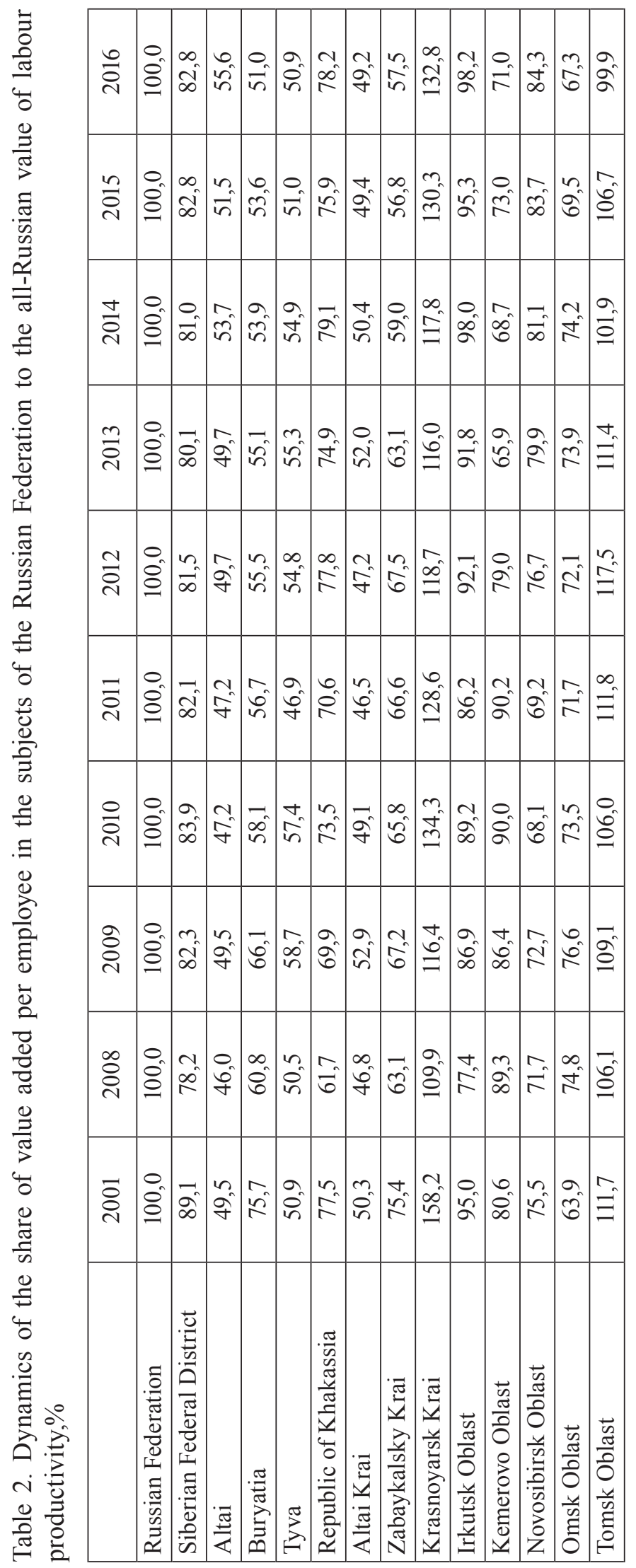


to 236.81 thousand rubles; in 2016 it was 242.02 thousand rubles. Thus, there is a slight strengthening of negative trends. A more complicated situation is observed in Kemerovo Oblast. Despite the fact that the average annual increase in the efficiency of labour resources use was almost equal to the average level of the efficiency growth in the SFD (13.94 \% - SFD, $13.56 \%$-Kemerovo Oblast), there had been a sharp decline in the share of value added per employee to the national value since 2012. In value terms, the value added per employee in the oblast had become less than the average value for the SFD since 2012. Whereas in 2012 this value was only 17.48 thousand rubles, in 2016 it was already 113.44 thousand rubles. Perhaps, it is necessary to talk about the negative trend formation in the economic development of the oblast.

Besides Krasnoyarsk Krai, only three subjects of the Russian Federation in the Siberian Federal District have the level of efficiency of labour resources use that exceeds the average level in the district. These are Novosibirsk, Irkutsk and Tomsk oblasts. In Tomsk Oblast, the excess of efficiency was consistent throughout the period under the analysis, but in 2014 and 2016 there was a slowdown in the efficiency growth. The excess of the average value for the district in 2013 amounted to 237.51 thousand rubles; in 2014 it was 173.06 thousand rubles; in 2015-217.12 thousand rubles; and in 2016-163.51 thousand rubles. It was this slowdown that led to a decrease in the ratio of the share of value added per employee in the oblast to the national average from $111.7 \%$ in 2001 to $99.9 \%$ in 2016. Novosibirsk Oblast reached the SFD average level of efficiency only in 2016. The growth rate was slightly higher than the national average $-15.26 \%$. We also observe an increase in the share of value added produced in the oblast per employee from $75.5 \%$ in 2001 to $84.3 \%$ in 2016. In Irkutsk Oblast, the level of efficiency in labour resources use had significantly decreased compared to the average national level in the crisis period of 2008-2009. Thus, in 2008, the ratio of added values in the oblast and in the Russian Federation as a whole amounted to $77.4 \%$ only. It increased to $86.9 \%$ in 2009 . Yet, the further growth slowed down, almost reaching the average national level of $98.2 \%$ by 2016 .

The value added in the territory of the subject of the Russian Federation is determined exclusively by the industrial structure of the region's national economy, the structure affecting the employment and wages. In 2016, the structure of the national economy of Krasnoyarsk Krai made it possible for the employed in the economy to receive an average monthly wage which was 1765 rubles more than the national average and 6905 rubles more than the average level of the SFD. Throughout the period under the analysis, the value of the "average monthly accrued wages of employees of 
organizations" indicator in Krasnoyarsk Krai exceeded both the national average and the average values for the SFD (Table 3).

Branches of Krasnoyarsk Krai specialization in 2016 are mining (specialization coefficient - 1.74), manufacturing (1.84), electricity, gas and water production and distribution (1.23), construction (1.1), and education (1.0). In 2011, the areas of specialization in the krai were mining (1.59), manufacturing (1.18), and construction (1.02) only. In the course of this period, the share of such economic activity as "electricity, gas and water production and distribution" increased from $3.6 \%$ to $4.8 \%$, the share of the "education" economic activity increased from $2.5 \%$ to $3 \%$. It is the specialization of the krai that determines the high average value of accrued wages.

Thus, regarding the "mining" economic activity, the average monthly accrued wages in the Russian Federation are appr. 80-90 \% higher than the average accrued wages in the economy of the Russian Federation as a whole for the entire period $(81.3 \%$ in 2013, $90.5 \%$ in 2016). In Krasnoyarsk Krai, the excess of average wages in the Russian economy as a whole in the mining industry is even higher: $123.4 \%$ in 2010, $114.4 \%$ in $2014,130.1 \%$ in 2015 , and $135.5 \%$ in 2016 . As for the average monthly wage in the manufacturing industry, which should be dominant in the structure of both the national economy and the regional economy, it does not exceed the national average. In 2010, the ratio of average wages in the industry and average wages in the economy as a whole was $91.06 \%$, in 2014-90.82 \%, in 2015-93.77\%, and in 2016-94.23\%. In Krasnoyarsk Krai, this ratio is in favor of the employed in the krai: $126.67 \%$ in 2010, $120.63 \%$ in 2014, $125.62 \%$ in 2015, and $127.13 \%$ in 2016. A similar situation is observed in the industry of "electricity, gas and water production and distribution", the average monthly wage in Krasnoyarsk Krai, regarding this economic activity, exceeds the average wage in the economy as a whole by about $20-25 \%$. In the field of "construction" as another specialization of the krai the ratio of average wages in the region and the economy as a whole had significantly reduced from $131.84 \%$ in 2010 to $107.06 \%$ in 2016, which is a consequence of the recent years' crisis. In the "education" sector, the average monthly wages in Krasnoyarsk Krai almost corresponds to the average national level - $80 \%$.

The ratio of the average monthly accrued wages in the Siberian Federal District to the value of the national economy as a whole is decreasing. The maximum value was fixed in 2001 (98.49 \%). The average monthly wage that year in Russia was 3239 rubles, in the SFD it was 3190 rubles. The minimum value in the SFD was reached at the end of the observed period (2016) - $86 \%$. Yet, it should be noted that in 2005 


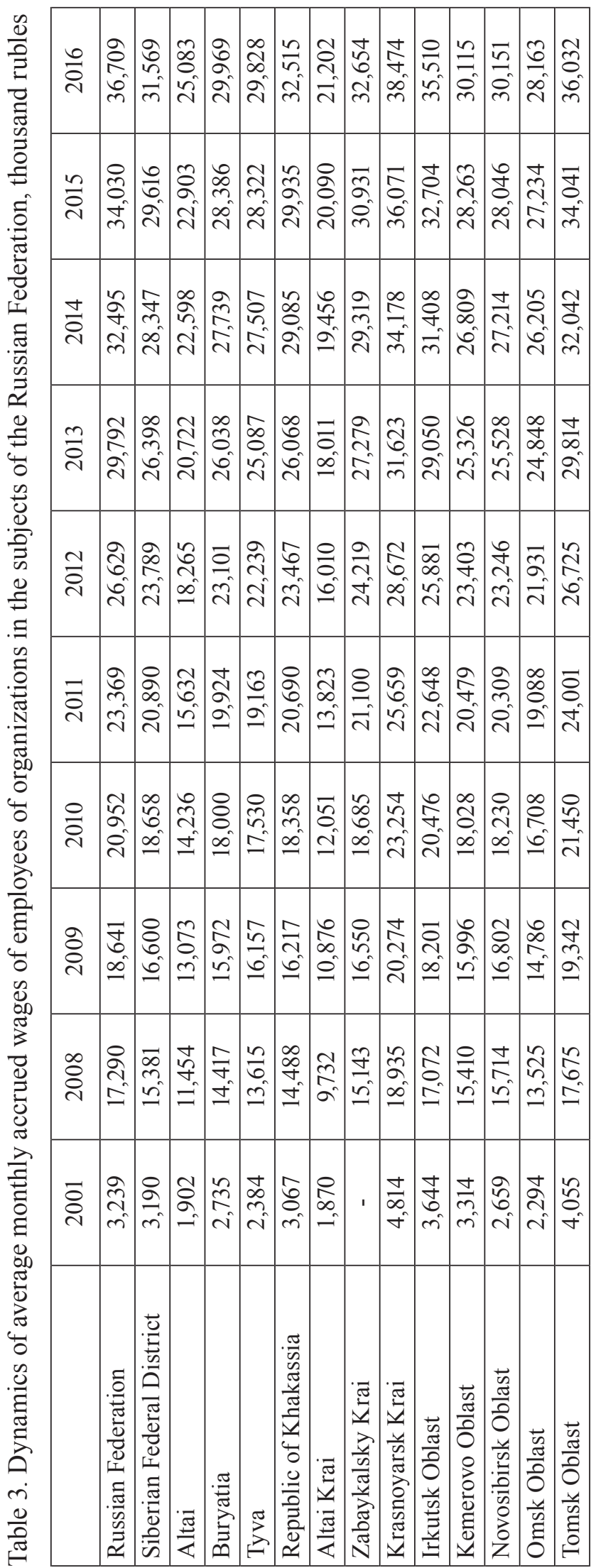


this ratio was $94.8 \%$, in 2008-2009 it decreased to $89 \%$, and, unfortunately, only a decrease (not a growth) is observed in the future. The reason for this slight regression is the lower average annual growth rate of average monthly wages in the SFD compared to the national average of $0.98 \%$.

Besides Krasnoyarsk Krai, the only territory of the SFD with the average accrued wages exceeding the average national level is Tomsk Oblast. However, the average annual rate of wage growth in Tomsk Oblast is $14.63 \%$, in the Russian Federation it is $16.39 \%$. By 2016 the average wage in the subject was $1.84 \%$ lower than the national average. Relative to the average value of the SFD, the average monthly wage in Tomsk Oblast during the entire period of 2001-2016 was 12-14 \% higher. In Irkutsk Oblast, the average wage was almost equal to the national average (more than $96 \%$ ), but exceeded the average for the SFD by $10-12 \%$. Other subjects of the Russian Federation, with the exception of Altai Krai and the Altai Republic with the average monthly wage of $79.45 \%$ and $67.16 \%$, respectively, to the average wage in the SFD, have a ratio of $85-95 \%$ to the wage of the SFD. Yet, the dynamics of the obtained results in multidirectional.

Regarding Buryatia, Tyva, the Republic of Khakassia, and Omsk Oblast, the average wage is growing faster in these subjects of the Russian Federation than in the SFD in general. This is largely provided by a state policy of wage growth in the social sector in accordance with the Decree of the President of the Russian Federation No. 597 “On measures on state social policy realization" from 07.05.2012 (Ukaz Prezidenta 597). The industrial structure of the economy in Buryatia and in Tyva has a very high value of the specialization coefficient in such sectors as "public administration and military security, social insurance", "education", "health and social services", which ensure high employment in these territories. The uniqueness of the Republic of Khakassia lies in its specialization in the "electricity, gas and water production and distribution" industry with the level of wages higher than the national average. Yet, due to technological features, this industry does not provide high employment in the territory. Wage growth in the republic is provided by the employment in the industries of specialization similar to the previous two subjects, as well as by specialization in such economic activity as "mining". Omsk Oblast specializes in the same industries of the "budgetary" sector. Its level of specialization is similar to that of the Republic of Khakassia, but with the extension to specialization in "manufacturing" and "construction", specialization coefficients being approximately equal to the values for Krasnoyarsk Krai. The crisis phenomena of 2014-2016 for the two mentioned above 
industrial sectors of specialization of Omsk Oblast resulted in lower growth rates of average wages in the subjects of the Russian Federation.

In Kemerovo Oblast, the average annual rate of wage growth is lower than in both the Russian Federation as a whole and the SFD. The main industry of specialization, providing employment in the subject of the Russian Federation, is mining, and namely coal mining. The tough competitive conditions in the industry and the consequences of the 2008-2009 crisis that are manifested in lower prices and demand volumes keep from wage increase at a higher rate compared to the Russian Federation as a whole and the SFD. The territory's specialization in the industries of the "budgetary" sector is insignificant. Thus, wage growth in these industries does not provide high growth rates. The average wage in Kemerovo Oblast, along with that of Tomsk Oblast, shows a decrease in the ratio of the average accrued wage in relation to the average national level by $20.28 \%$, to the average level of the SFD - by $8.5 \%$.

In general, these are Krasnoyarsk Krai, Tomsk Oblast, and Irkutsk Oblast that are the leaders in terms of average wages in the Siberian Federal District. Kemerovo Oblast, ranking the seventh, demonstrates a slowdown in wage growth. The regions with the lowest level of average wages are Altai Krai, the Altai Republic, and Omsk Oblast. The regions with the value of the "share of the average annual accrued wages of employees of organizations in value added per employee in the subject of the Russian Federation" indicator of more than $50 \%$ are Buryatia, Tyva, Zabaykalsky Krai, the Altai Republic, Altai Krai, Kemerovo Oblast, Omsk Oblast, and the Republic of Khakassia. The share of wages in value added in these subjects of the Russian Federation exceeds the national average. The regions with the value of the analyzed indicator of less than $50 \%$ are Irkutsk Oblast, Tomsk Oblast, Novosibirsk Oblast, and Krasnoyarsk Krai (Table 4).

It is worth while noting that in Krasnoyarsk Krai the average annual growth rate of average wages per employee for the 2001-2016 period is the lowest in the federal district. It amounts to $113.87 \%$ only. In general, the growth rate in Russia is $116.39 \%$, in the SFD - $115.4 \%$. The maximum value of the share of wages in value added produced by one employee was observed in 2009. It amounted to $45.31 \%$. As for the minimum one, it was $33.16 \%$ in 2001. In the course of the 2001-2009 period the growth rate was $12.15 \%$, the absolute increase in the average monthly accrued wages of employees being 15460 rubles. During this ten-year period the increase in value added in Krasnoyarsk Krai was equal to 362710 rubles per employee per year, which corresponds to the growth rate of $308.19 \%$. The consequences of the 2008-2009 crisis 


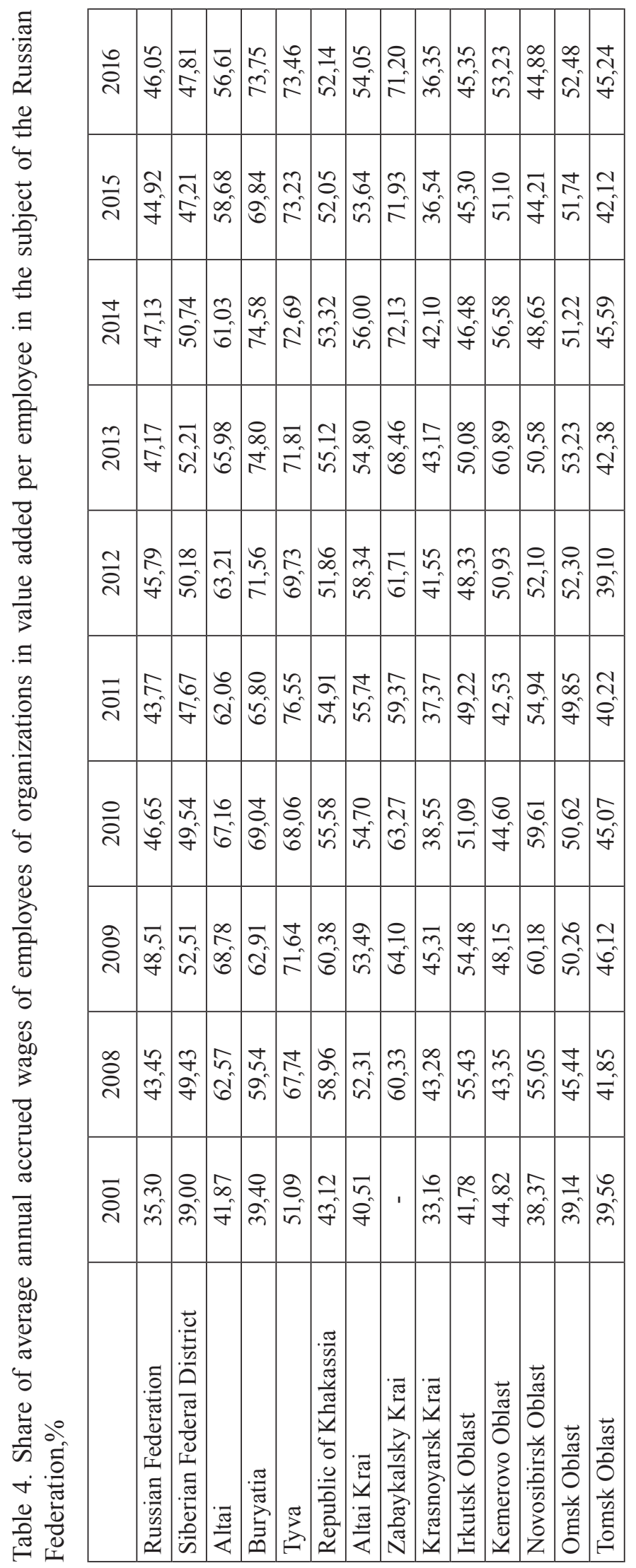


on the Krasnoyarsk Krai labour market began to affect the region in 2010: the wage growth rate was lower than the growth rate of value added. A similar situation was observed from 2014 to 2016: the labour productivity growth outpaces the wage growth. Economic losses of the crisis period are restored by businesses at the expense of the employed. At that it is necessary to remember that a high level of employment in Krasnoyarsk Krai is provided by such economic activities as education and health care with the value of specialization coefficients of more than 0.80 , the wage growth being provided by budgetary funds.

In 2016, in Tomsk Oblast, the share of average wages in value added was $45.24 \%$, the employees' average monthly accrued wages were 36032 rubles, which is only 2442 rubles lower than in Krasnoyarsk Krai. Yet, the share of value added distributed to the employed was higher by $8.89 \%$. In Irkutsk Oblast, the share of average wages in value added in 2016 was $45.35 \%$. The value was $9 \%$ higher than in Krasnoyarsk Krai, the leading region, and was almost equal to the value for Tomsk Oblast (only $0.11 \%$ higher). The employees' average monthly accrued wages were 35510 rubles. It is 2964 rubles less than compared with the leading region and 552 rubles less than compared with the value for Tomsk Oblast.

Specialization of Tomsk and Irkutsk oblasts are identical, regarding such types of economic activity with high added value as "mining" and "transport and communications". In such financial activities and industries as "real estate transactions, rent and services", "manufacturing", and "construction" the coefficients of regional specialization are similar. Yet, these industries are not the ones of the territories' specialization. The growth of employment in these industries is provided by the wage growth. These subjects of the Russian Federation specialize in the "budgetary" segment of the national economy: public administration and military security, social insurance, education, health care, and social services. Wage growth is determined by the state policy.

\section{Conclusion}

Economic growth in the Russian Federation should be secured by improving the efficiency of use of all the resources of the country's national economy. Increased labour productivity based on scientific and technological changes should be accompanied by corresponding changes in the current systems of relations in the labor market: creation of highly productive jobs determines the requirements for professional competencies of employees with high demands on working conditions and wages. 
Traditional approaches to the research on the interdependence of labour productivity and wages justify the proportionality of wage growth to productivity growth. The results of the analysis lead to the conclusion that the share of wages is low in the regions specializing in industries with high productivity and average wages. Building a system of targets for the territory socio-economic development based on average indicators can lead to false ideas about the well-being of the region. Business begins to focus on the level of average wages in the region, thereby forming a "closed" regional decisionmaking system. The lack of mechanisms of state regulation of wage systems in the market sector attaches particular importance to the minimum wage increase, which, among other things, allows withdrawing a part of wages from the shadow sector.

\section{References}

Aganbegian, A.G. (2017). Investitsii v osnovnoi kapital i vlozheniia v chelovecheskii kapital - dva vzaimosviazannykh istochnika sotsial'no-ekonomicheskogo rosta [Investments in fixed assets and investments in human capital are two interconnected sources of socio-economic growth]. In Problemy prognozirovaniia [Studies on Russian Economic Development], 4, 17-19.

Ivanov, V.N., Suvorov, A.V. (2012). Zadachi snizheniia urovnia bednosti naseleniia i stimulirovaniia potrebitel'skogo sprosa v rossiiskoi ekonomike [The tasks of reducing the poverty level of the population and stimulating consumer demand in the Russian economy]. In Problemy prognozirovaniya [Studies on Russian Economic Development], 4, 100-117.

Konstitutsiia RossiiskoiFederatsii (priniata vsenarodnym golosovaniem 12.12.1993) (s uchetom popravok, vnesennykh Zakonami RF o popravkakh $k$ Konstitutsii RF ot 30.12.2008 № 6-FKZ, ot 30.12.2008 № 7-FKZ, ot 05.02.2014 № 2-FKZ, ot 21.07.2014 № 11-FKZ) [The Constitution of the Russian Federation (adopted by popular vote on December 12, 1993) (with amendments introduced by the Laws of the Russian Federation on amendments to the Constitution of the Russian Federation of December 30, 2008 No. 6-FKZ, of December 30, 2008 No. 7-FKZ, of May 02, 2014 No. 2-FKZ, of July 21, 2014 No. 11-FKZ)], SPS Consultant.

Prikaz Ministerstva ekonomicheskogo razvitiia Rossiiskoi Federatsii ot 24.04.2018 g. № 274 “Ob utverzhdenii metodiki rascheta pokazatelia "indeks proizvoditel'nosti truda" [Order of the Ministry of Economic Development of the Russian Federation No. 274 "On approval of the method of calculating the indicator of "Labour Productivity Index" from April 24, 2018], SPS Consultant. 
Prikaz Ministerstva truda $i$ sotsial'noi zashchity Rossiiskoi Federatsii ot 24.08.2018 g. № 550n “Ob ustanovlenii velichiny prozhitochnogo minimuma na dushu naseleniia i po osnovnym sotsial'no-demograficheskim gruppam naseleniia $v$ tselom po Rossiiskoi Federatsii za II kvartal 2018 goda" [Order of the Ministry of Labour and Social Protection of the Russian Federation No. 550n "On setting the size of a living wage per capita and regarding the major socio-demographic population groups in the Russian Federation for the II Quarter of 2018" from August 24, 2018], SPS Consultant.

Sobolev, E.N. (2017). Oplata truda v sisteme sotsial'no-trudovykh otnoshenii: stereotipy $i$ rossiiskie reali: Nauchnyi doklad [Remuneration in the system of social and labour relations: stereotypes and Russian realities: Scientific Report]. Moscow, Institut ekonomiki RAN, 50 p.

Ukaz Prezidenta Rossiiskoi Federatsii ot 07.05.2018 g. № 204 "O natsional'nykh tseliakh i strategicheskikh zadachakh razvitiia Rossiiskoi Federatsii do 2024 g." [Presidential Decree No. 204 "On national goals and strategic problems of the Russian Federation development for the period till 2024” from May 07, 2018], SPS Consultant.

Uziakov, M.N., Shirokov, A.A. (2012). Makroekonomicheskaia dinamika rossiiskoi ekonomiki $\mathrm{v}$ dolgosrochnoi perspective [Macroeconomic dynamics of the Russian economy in the long term]. In Problemy prognozirovaniia [Studies on Russian Economic Development], 6, 14-34.

\section{Региональная дифференциация производительности труда и распределение добавленной стоимости}

\section{Е.Н. Почекутова}

Сибирский федеральныий университет Россия, 660041, Красноярск, пр. Свободный, 79

В статье рассмотрена проблема распределения добавленной стоимости при формировании оплаты труда. Повымение эффективности общественного производства в России связывают с необходимостью инновационных, технологических изменений, которые должсны привести к росту производительности труда. Российская Федерация не является страной с высоким уровнем эффективности производства. Зачастую именно этот факт служит доводом для обоснования низкой заработной платы в стране. Парадокс существования в стране категории работающих граждан - «работающих бедных» - основан, в том числе, на низком уровне гарантированных доходов - минимальном размере оплаты труда. Минимальный размер оплаты труда до 1 мая 2018 г. не соответствовал прожиточному минимуму. Размер средней 
заработной платы в регионе зависит от присутствия на территории отраслей с высокой добавленной стоимостью, т.е. от отраслевой специализации. Сложившая практика в России такова, чем выше уровень средней заработной платы, тем ниже доля добавленной стоимости, приходящейся на оплату труда. Регионы, которые не имеют специализации в видах экономической деятельности с высокой добавленной стоимостью, более реально оченивают уровень соииально-экономического развития, основывая свое стратегическое развитие на отраслях, формирующих более справедливые системы оплаты труда и выравнивающих уровень средней заработной плать.

Ключевые слова: производительность труда, эффективность общественного производства, добавленная стоимость на одного занятого, доля оплать труда, субъект Российской Федеращии.

Научная спещииальность: 08.00.00 - экономические науки. 